\title{
Purification and amino acid sequence of a bacteriocin produced by Pediococcus acidilactici
}

\author{
Juan Carlos Nieto lozano, ${ }^{2}$ Jon Nissen Meyer, ${ }^{1}$ KnUt Sletten, ${ }^{3}$ Carmen Peláz ${ }^{2}$ and \\ INGOLF F. NES ${ }^{1 *}$
}

${ }^{1}$ Laboratory of Microbial Gene Technology, NLVF, Post Box 51, N-1432 As, Norway

${ }^{2}$ Consejo Superior de Investigaciones Cientificas, Instituto del Frio, Madrid, Spain

${ }^{3}$ Department of Biochemistry, University of Oslo, Oslo, Norway

(Received 31 December 1991; revised 2 April 1992; accepted 27 April 1992)

\begin{abstract}
A bacteriocin produced by Pediococcus acidilactici has been purified to homogeneity by a rapid and simple fourstep purification procedure which includes ammonium sulphate precipitation, chromatography with a cationexchanger and Octyl Sepharose, and reverse-phase chromatography. The purification resulted in an approximately 80000 -fold increase in the specific activity and about a 6-fold increase in the total activity. The amino acid composition and sequencing data indicated that the bacteriocin contained $43-44$ amino acid residues. The predicted $M_{\mathrm{r}}$ and isoelectric point of the bacteriocin are about 4600 and 8.6, respectively. Comparing the amino acid sequence of this bacteriocin with the sequences of leucocin A-UAL 187, sakacin P and curvacin A (bacteriocins produced by Leuconostoc gelidum, Lactobacillus sake and Lactobacillus curvatus, respectively) revealed that all four bacteriocins had in their N-terminal region the sequence Tyr-Gly-Asn-Gly-Val-Xaa-Cys, indicating that this concensus sequence is of fundamental importance for this group of bacteriocins. The bacteriocin from $P$. acidilactici and sakacin $P$ were very similar, having at least 25 common amino acid residues. The sequence similarity was greatest in the $\mathrm{N}$-terminal half of the molecules -17 of the first 19 residues were common - indicating the fundamental importance of this region. Leucocin A-UAL 187 and curvacin A had, respectively, at least 16 and 13 amino acid residues in common with the bacteriocin from $P$. acidilactici.
\end{abstract}

\section{Introduction}

Bacteriocins are proteinaceous compounds that are lethal to bacteria which are closely related to the bacteriocin-producing species (Tagg et al., 1976). These compounds are produced by various lactic acid bacteria, such as lactobacilli, lactococci and pediococci (Klaenhammer, 1988). There has been much interest in bacteriocins produced by lactic acid bacteria, in part due to their potential use as antibacterial agents for improving the safety of feed and food fermentation products.

Although a number of bacteriocins produced by lactic acid bacteria have been described (Klaenhammer, 1988), only a few have been extensively characterized. Nisin and lactococcin A, produced by Lactococcus lactis subsp.

\footnotetext{
* Author for correspondence. Tel. 47-9-949469; fax 47-9-941465; E-mail BIOIFN@NLH10000.NLH.NO.

Abbreviation: $\mathrm{BU}$, bacteriocin unit.

The amino acid sequence data reported in this paper have been submitted to PIR and have been assigned the accession number A41823.
}

lactis and subsp. cremoris, respectively, are perhaps the most thoroughly studied. Their primary structures have been determined (Gross \& Morell, 1971; Hurst, 1981; Holo et al., 1991), their genes have been cloned and sequenced by several groups (Buchman et al., 1988; Dodd et al., 1990; Kaletta \& Entian, 1989; Holo et al., 1991 ; van Belkum et al., 1989, 1991 a), and their mode of action has to some extent been elucidated (Sahl et al., 1987; van Belkum et al., 1991 b). Leucocin A-UAL 187, a bacteriocin produced by Leuconostoc gelidum, was recently characterized and the gene encoding the bacteriocin was cloned (Hastings et al., 1991). Amongst lactobacilli, bacteriocins which have been purified to homogeneity and sequenced, and/or whose genes have been cloned and sequenced, are lactocin S (Mørtvedt $e t$ al., 1991), lactacin F (Muriana \& Klaenhammer, $1991 a, b$ ), and helveticin J (Joerger \& Klaenhammer, 1990).

In recent years a number of reports dealing with bacteriocins in pediococci have been published. One report describes a plasmid-linked bacteriocin, which was 
termed pediocin PA-1, from Pediococcus acidilactici (Gonzales \& Kunka, 1987). An antimicrobial peptide designated pediocin $\mathrm{AcH}$ was purified and characterized from $P$. acidilactici, but no information on the amino acid sequence was presented (Bhunia et al., 1988). A Pediococcus pentosaceus strain has also been reported to produce a bacteriocin, termed pediocin A (Daeschel \& Klaenhammer, 1985). Pediocin A was claimed to be associated with a $13.6 \mathrm{MDa}$ plasmid.

This study describes the purification and characterization of a bacteriocin produced by a $P$. acidilactici strain. After submitting this manuscript we were informed that purification and amino acid sequencing of pediocin PA-1 had been done by J. T. Henderson and co-workers (Henderson et al., 1992). The primary amino acid sequence of pediocin PA-1 reported by Henderson et al. (1992) is identical to the bacteriocin discussed in this paper. Therefore, we have also termed our bacterioccin pediocin PA-1 in order to avoid confusion.

\section{Methods}

Bacterial strains and media. The pediocin PA-1 producer, Pediococcus acidilactici, was isolated from commercial starter cultures obtained from Chr. Hansen Laboratories, Denmark. The indicator organism used in pediocin PA-1 assay, Pediococcus pentosaceus FBB61, was obtained from M. Daeschel, North Carolina State University, Raleigh, USA. Both strains were grown at $30^{\circ} \mathrm{C}$ in MRS broth (Oxoid). Lactococcus lactis subsp cremoris IL 1403 was grown in M17 broth (Oxoid) and was obtained from M. C. Chopin, INRA, Rennes, France.

Bacteriocin assay. Pediocin PA-1 was quantified in a microtitre plate assay system (Geis et al., 1983). Each well of the mictotitre plate contained $200 \mu \mathrm{l}$ of MRS broth, bacteriocin fractions at twofold dilutions, and the indicator organism $\left(\mathrm{OD}_{600} 0 \cdot 1\right)$. The microtitre plate cultures were incubated for about $3 \mathrm{~h}$ at $30^{\circ} \mathrm{C}$, after which growth inhibition of the indicator organism was measured spectrophotometrically at $600 \mathrm{~nm}$ with a Dynatech Microplate Reader. One bacteriocin unit (BU) was defined as the amount of bacteriocin which inhibited growth of the indicator organism by $50 \%(50 \%$ of the turbidity of the control culture without bacteriocin).

Bacteriocin purification. Pediocin PA-1 was purified from 1-litre cultures of $P$. acidilactici grown to the stationary phase. The cells were pelleted by centrifugation at $4000 \mathrm{~g}$ for $15 \mathrm{~min}$ at $4{ }^{\circ} \mathrm{C}$, after which $400 \mathrm{~g}$ of ammonium sulphate per litre culture supernatant was added. The protein precipitate was pelleted by centrifugation at $7000 \mathrm{~g}$ for $20 \mathrm{~min}$ and solubilized in $20 \mathrm{~mm}$-sodium phosphate buffer, pH 6.8 (buffer A, $250 \mathrm{ml}$ per litre culture) (fraction I). Fraction I was applied to a $7 \mathrm{ml} \mathrm{S}$-Sepharose Fast Flow cation-exchange column equilibrated with buffer $A$, and after washing the column with $20 \mathrm{ml}$ of buffer $\mathrm{A}$, pediocin PA-1 was eluted with $40 \mathrm{ml} 1 \mathrm{M}-\mathrm{NaCl}$ in buffer A (fraction II). Ammonium sulphate $(10 \%, w / v$, final concentration) was added to fraction II, after which the fraction was applied to a $2 \mathrm{ml}$ OctylSepharose CL-4B column equilibrated with $10 \%(w / v)$ ammonium sulphate in buffer A. The column was then washed with $8 \mathrm{ml}$ of buffer $A$, and pediocin PA-1 activity was eluted with $10 \mathrm{ml} 70 \%(\mathrm{v} / \mathrm{v})$ ethanol and $30 \%$ buffer A (fraction III). Fraction III was diluted to $50 \mathrm{ml}$ with $\mathrm{H}_{2} \mathrm{O}$ containing $0 \cdot 1 \%(\mathrm{v} / \mathrm{v})$ trifluoroacetic acid (TFA) and subsequently applied to a $\mathrm{C}_{2} / \mathrm{C}_{18}$ reverse-phase column, PepRPC $\mathrm{HR} 5 / 5$, equilibrated with 2-propanol/ $\mathrm{H}_{2} \mathrm{O}(10: 90, \mathrm{v} / \mathrm{v})$ containing $0.1 \%$ TFA. Pediocin PA-1 was eluted with a linear gradient ranging from 20 to $40 \%$ 2-propanol containing $0 \cdot 1 \%$ TFA (fraction IV). All the purification steps were performed at room temperature, and all the chromatographic equipment was obtained from Pharmacia-LKB Biotechnology.

SDS-PAGE. SDS-PAGE was carried out using PhastGel homogeneous $20 \%$ gels, Phast-Gel SDS buffer strips, and the PhastSystem (Pharmacia-LKB Biotechnology) according to the manufacturer's recommendations. The $M_{\mathrm{r}}$ standards (Pharmacia-LKB Biotechnology) consisted of five peptides with $M_{\mathrm{r}}$ values between 2560 and 17200 .

Amino acid composition and sequencing. The purified bacteriocin (fraction IV) was hydrolysed and analysed on an amino acid analyser as described previously (Fykse et al., 1988). The amino acid sequence was determined by Edman degradation using an Applied Biosystems 477A automatic sequencer with an on-line $120 \mathrm{~A}$ phenylthiohydantoin amino acid analyser (Cornwell et al., 1988). The C-terminal part of the sequence was obtained after cyanogen bromide cleavage of pediocin PA-1 as described by Sletten \& Husby (1974)

\section{Results and Discussion}

\section{Purification of bacteriocin}

Pediocin PA-1 was produced constitutively and maximum activity was found in the culture medium in the stationary phase of growth. A fourfold concentration of pediocin PA-1, approximately a fourfold increase in the specific activity, and about a $40 \%$ recovery of the activity, was obtained after ammonium sulphate precipitation (Table 1, fraction I). The specific activity increased more than 600 -fold, and the recovery remained at about $40 \%$, after binding pediocin PA-1 in fraction I to a cation exchanger and eluting it with $1 \mathrm{M}-\mathrm{NaCl}$ (Table 1, fraction II). After binding pediocin PA-1 in fraction II to Octyl-Sepharose and eluting it with $70 \%$ ethanol, an approximately 13000 -fold increase in the specific activity was obtained and the recovery increased to $200 \%$ (Table 1 , fraction III).

When fraction III was applied to the reverse-phase column, pediocin PA-1 activity coeluted with the major absorbance peak at about $28 \%$ propanol (Fig. 1). After this reverse-phase chromatography step the specific activity and the yield had increased by more than 80000 fold and to about $600 \%$, respectively (Table 1 , fraction IV). The increase in the activity after binding of pediocin PA-1 to Octyl-Sepharose (fraction III, Table 1) and to the reverse-phase column (fraction IV, Table 1) may perhaps be due to an activation of pediocin PA-1 in the more hydrophobic milieu provided by the $70 \%$ ethanol and $28 \%$ propanol. Judging from the chromatogram (Fig. 1) pediocin PA-1 appears at this stage to be pure. The purification procedure is rapid, in that it may be carried out in less than $5 \mathrm{~h}$, and it resulted in a high bacteriocin yield. 
Table 1. Purification of pediocin PA-1

\begin{tabular}{|c|c|c|c|c|c|c|}
\hline Fraction & $\begin{array}{l}\text { Vol. } \\
(\mathrm{ml})\end{array}$ & $\begin{array}{l}\text { Total } \\
A_{280}^{*}\end{array}$ & $\begin{array}{c}\text { Total } \\
\text { activity } \\
(\mathrm{BU})\end{array}$ & Sp. act. $\dagger$ & $\begin{array}{c}\text { Increase } \\
\text { in } \\
\text { sp. act. } \dagger\end{array}$ & $\begin{array}{l}\text { Yield } \\
(\%)\end{array}$ \\
\hline $\begin{array}{l}\text { Culture supernatant } \\
\text { Ammonium sulphate }\end{array}$ & 1000 & 23000 & $50 \times 10^{6}$ & 2200 & 1 & 100 \\
\hline $\begin{array}{l}\text { precipitation (fraction I) } \\
\text { Binding to cation }\end{array}$ & 250 & 2060 & $19 \times 10^{6}$ & 9200 & 4 & 38 \\
\hline $\begin{array}{l}\text { exchanger (fraction II) } \\
\text { Binding to Octyl- }\end{array}$ & 40 & 14 & $20 \times 10^{6}$ & $1.4 \times 10^{6}$ & 640 & 40 \\
\hline $\begin{array}{l}\text { Sepharose (fraction III) } \\
\text { Reverse-phase }\end{array}$ & 10 & $3 \cdot 5$ & $100 \times 10^{6}$ & $28 \times 10^{6}$ & 12700 & 200 \\
\hline chromatography (fraction IV) & $1 \cdot 5$ & 1.7 & $300 \times 10^{6}$ & $176 \times 10^{6}$ & 80000 & 600 \\
\hline
\end{tabular}

* Total $A_{280}$ is the absorbance at $280 \mathrm{~nm}$ multiplied by the volume in $\mathrm{ml}$. $\uparrow$ Specific activity is bacteriocin units (BU) divided by the $A_{280}$.

The purified bacteriocin was bactericidal against other pediococci, and was approximately 10000 -fold more potent against pediococci than against Lactococcus lactis subsp. cremoris IL1403 (data not shown).

\section{$S D S-P A G E$ analysis of purified bacteriocin}

When pediocin PA-1 in fraction IV was analysed by SDS-PAGE, a single band was detected, migrating with an $M_{\mathrm{r}}$ of $3000-4000$ (Fig. 2). This is consistent with the pediocin PA-1 preparation being pure and indicates that the bacteriocin is a relatively small peptide, as are lactococcin A (Holo et al., 1991), lactacin F (Muriana \&

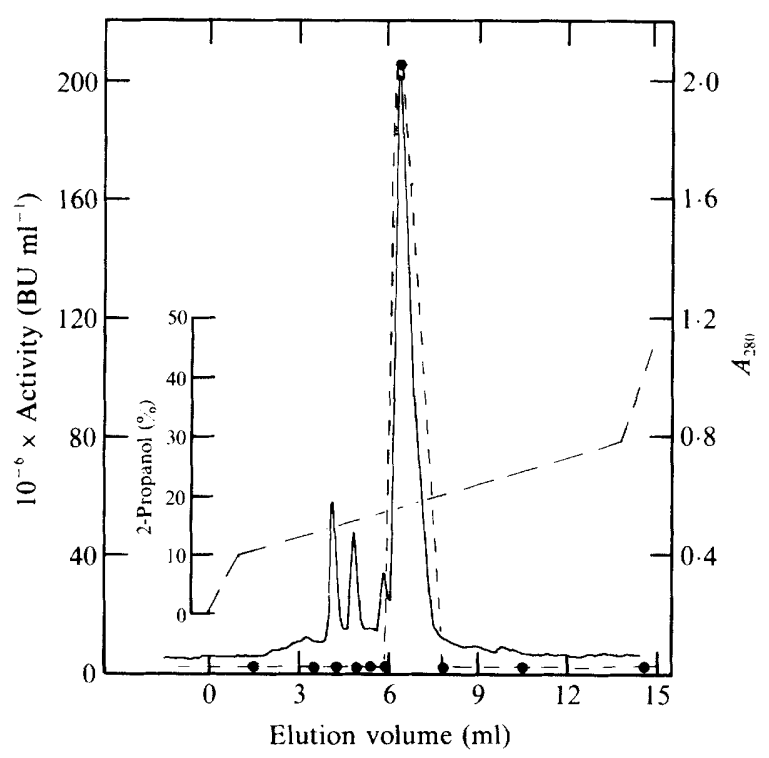

Fig. 1. Reverse-phase chromatography of fraction III. The amount applied to the column was obtained from approximately 1 litre of culture. -..., Bacteriocin activity;,$- A_{280} ;--$, , 2-propanol gradient.
Klaenhammer, $1991 a, b$ ), lactocin S (Mørtvedt et al., 1991), and leucocin A-UAL 187 (Hastings et al., 1991).

\section{Amino acid composition and sequence}

The amino acid composition of pediocin PA-1 (fraction IV) indicated that the peptide is 41 residues long, not including the possible presence of tryptophan, which was not measured (Table 2). Starting with the $\mathrm{N}$-terminus, 43 amino acid residues were sequenced (Fig. $3 a$ ). Two alternatives were found at residue positions 14, 24 and 30. Judging from the amino acid composition data, the most likely alternative is Cys, Cys and Ala at positions 14,24 and 30 , respectively. This alternative is also consistent with the sequence similarity we have found

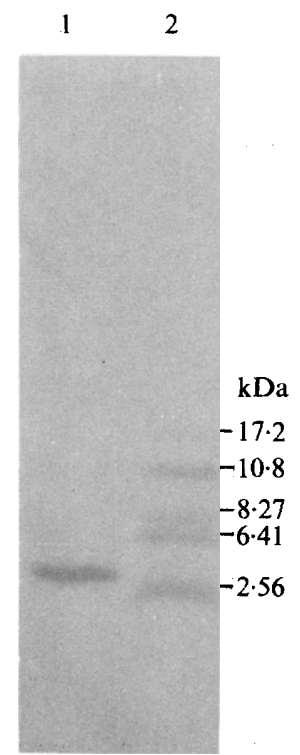

Fig. 2. SDS-PAGE analysis of the bacteriocin in fraction IV. Lanes: 1 , pediocin PA-1; 2, standards. 
(a)

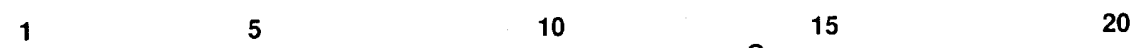

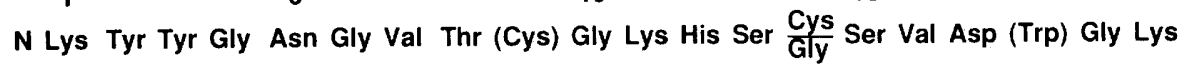

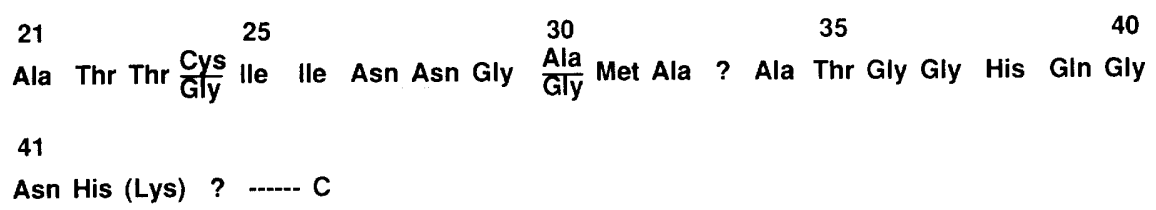

(b) $\begin{array}{llllr}1 & 5 & 10 & 15 & 20\end{array}$ Pediocin PA-1 N Lys Tyr Tyr Gly Asn Gly Val Thr Cys Gly Lys His Ser Cys Ser Val Asp Trp Gly Lys Sakacin P N Lys Tyr Tyr Gly Asn Gly Val His Cys Gly Lys His Ser Cys Thr Val Asp Trp Gly Thr Leucocin A N Lys Tyr Tyr Gly Asn Gly Val His Cys Thr Lys Ser Gly Cys Ser Val Asn Trp Gly Glu Curv. A N Ala Cys Ser Tyr Gly Asn Gly Val Tyr Cys Asn Asn Lys Lys Ser Trp Val Asn Gly Gly Glu 26011 1116 21 $\begin{array}{lllll}21 & 25 & 30 & 35 & 40\end{array}$

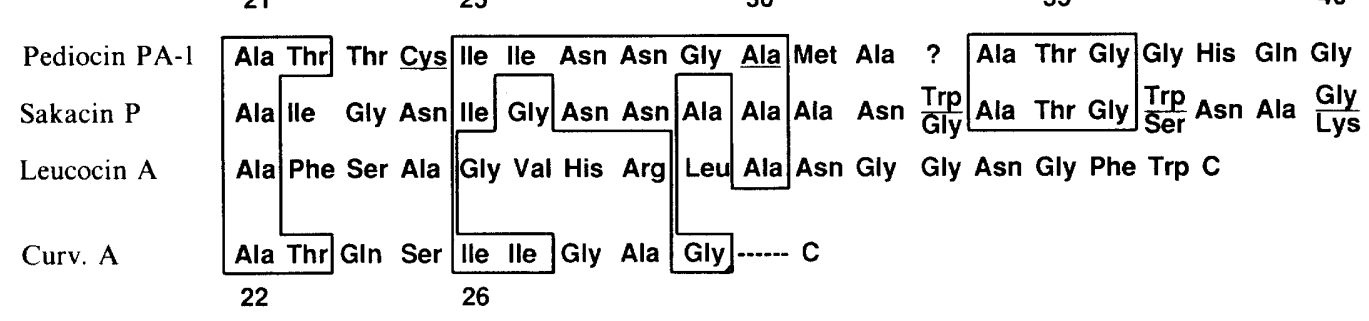
41 Pediocin PA-1 Asn His Lys ? -...... C Sakacin P Gly $\mathrm{C}$

Fig. 3. (a) Amino acid sequence of pediocin PA-1. Uncertain amino acids are in parentheses. Where two amino acids are shown, this indicates the presence of either one or the other amino acid, the upper one being the more likely. A question mark indicates an unidentified amino acid, the presence of Trp or Cys being the most likely. $\mathrm{N}$ and $\mathrm{C}$ indicate the $\mathrm{N}$ - and C-terminal ends of the peptide, respectively. (b) Comparison of the amino acid sequence of pediocin PA-1, sakacin P, leucocin A-UAL 187 (leucocin A), and curvacin $A$ (curv. A). The numbering above the sequence refers to the position of the amino acids in pediocin PA-1, sakacin P and leucocin AUAL 187, whereas the numbering beneath the sequence refers to the position of the amino acids in curvacin $A$. The boxes enclose common amino acid residues. In the cases where there was ambiguity in the amino acid determination for pediocin PA-1, as indicated in $(a)$, only the most probable amino acid is included in the sequence shown in $(b)$. The uncertain amino acids in the sequence for pediocin PA-1 have been underlined. The amino acid sequence for leucocin A-UAL 187 is from Hastings et al. (1991), and the sequences for sakacin P and curvacin A are from Tichaczek et al. (1992).

between pediocin PA-1 and sakacin P (see discussion below). The identity of the amino acid residue at position 33 and the possible presence of an amino acid residue at position 44 remain uncertain (Fig. $3 a$ ), although it is likely that they are Trp and Cys, respectively. These amino acids are generally more difficult to identify. The sequence similarity between pediocin PA-1 and sakacin $\mathbf{P}$ (see below) suggests the presence of Trp in position 33 . Moreover, as the amino acid composition data predict the presence of four Cys residues, whereas only three are accounted for in the sequence data, one more Cys residue is probably present, possibly at position 44 , which then is likely to be the C-terminal residue. The $M_{\mathrm{r}}$ and the theoretical isoelectric point of pediocin PA-1 would then be 4640 and 8.65 , respectively. The only clear discrepancy between the amino acid composition data and the sequence would then be that two Ile residues were found in the sequence, whereas only one was predicted from the amino acid composition data (Table 2, Fig. 3a).

Leucocin A-UAL 187, sakacin P and curvacin A, bacteriocins produced by Leuconostoc gelidum, Lactobacillus sake and Lactobacillus curvatus, respectively, have 
Table 2. Amino acid composition of pediocin $P A-1$

\begin{tabular}{lccc}
\hline \hline & \multicolumn{2}{c}{ Amino acid analysis* } & \\
\cline { 2 - 3 } \multicolumn{1}{c}{$\begin{array}{c}\text { Amino } \\
\text { acid }\end{array}$} & nmol & $\begin{array}{c}\text { Residues per } \\
\text { molecule }\end{array}$ & $\begin{array}{c}\text { Residues found } \\
\text { by sequencing }\end{array}$ \\
\hline Ala & $8 \cdot 10$ & $4(5)$ & $4 \dagger$ \\
Arg & NP & 0 & 0 \\
Asp/Asn & $8 \cdot 96$ & 5 & 5 \\
Cys & 7.15 & 4 & $3 \ddagger$ \\
Glu/Gln & 2.13 & 1 & 1 \\
Gly & 14.3 & 8 & $8 \S$ \\
His & 6.35 & $3(4)$ & 3 \\
Ile & 1.39 & 1 & 2 \\
Leu & NP & 0 & 0 \\
Lys & 7.42 & 4 & 1 \\
Met & 1.78 & 1 & 0 \\
Phe & NP & 0 & 0 \\
Pro & NP & 0 & 2 \\
Ser & 3.89 & 2 & 4 \\
Thr & 7.26 & 4 & $1(210$ \\
Trp & NM & - & 2 \\
Tyr & 3.51 & 2 & \\
Val & 3.61 & 2 & $42(43)$ \\
Total no. & & & \\
of residues & & $41(43)$ & \\
\hline \hline
\end{tabular}

* A $50 \mu \mathrm{l}$ sample, containing approximately $1 \mu \mathrm{g}$ protein, was analysed to determine the amount ( $\mathrm{nmol}$ ) of each residue. The lowest amount (nmol) was assumed to represent one amino acid residue and the numbers of each amino acid residue were calculated accordingly. NP, Not present; NM, not measured.

$\dagger$ Including the probable presence of Ala at position 30 .

$\ddagger$ Including the probable presence of Cys at positions 14 and 24 .

$\S$ Not including the possible presence of Gly at position 14,24 and 30.

\|Including the possibility that $\operatorname{Trp}$ may be present at position 33 .

recently been purified and sequenced (Hastings et al., 1991; Tichaczek et al., 1992). All three of these bacteriocins have in their $\mathrm{N}$-terminal region the sequence Tyr-Gly-Asn-Gly-Val-Xaa-Cys, which is also present in the N-terminal region of pediocin PA-1 (Fig. $3 b$ ). The presence of this sequence in four bacteriocins produced by different bacteria suggests that this region is of fundamental importance for bacteriocin activity. The sequence may perhaps directly cause the bactericidal effect or it might be important in determining the bacteriocin's target-cell specificity. Pediocin PA-1 and sakacin $\mathbf{P}$ are as a whole very similar, having at least 25 common amino acid residues (Fig. $3 b$ ). The suggestion above, that Cys, Cys and Ala are at positions 14, 24 and 30 , respectively, is consistent with the sequence similarity between pediocin PA-1 and sakacin P (Fig. $3 b$ ). This sequence similarity also suggests that the unidentified amino acid residue number 33 in pediocin PA-1 may be Trp (Fig. $3 b$ ), and that the fourth Cys residue predicted by the amino acid composition analysis might be the $\mathrm{C}$ - terminal residue, at position 44. Pediocin PA-1 had at least 16 and 13 amino acid residues in common with leucocin A-UAL 187 and curvacin A, respectively (Fig. $3 b$ ). The number of common residues between these four bacteriocins may in fact be higher, since not all the residues have been unambiguously identified in all of these bacteriocins. The sequence similarity was greatest in the $\mathrm{N}$-terminal half of the molecules. Seventeen of the first 19 amino acid residues were identical between pediocin PA-1 and sakacin P (Fig. 3b), indicating the importance of this part of the molecule. Determining whether these bacteriocins have similar target-cell specificities may clarify if the regions in which these bacteriocins are similar determine target-cell specificity. Constructing hybrid bacteriocins may also clarify what parts of the pediocin PA-1 molecule cause the bactericidal effect and what parts determine target-cell specificity. By constructing hybrid bacteriocin molecules it may also be possible to generate bacteriocins with new target-cell specificity spectra desirable for their use as antimicrobial agents.

\section{References}

van Belkum, M. J., Hayema, B. J., Geis, A., KoK, J. \& Venema, G. (1989). Cloning of two bacteriocin genes from a lactococcal bacteriocin plasmid. Applied and Environmental Microbiology 55, 1187-1191.

van Belkum, M. J., Hayema, B. J., Jeeninga, R. E., KoK, J. \& VENEMA, G. (1991 a). Organization and nucleotide sequences of two lactococcal bacteriocin operons. Applied and Environmental Microbiology 57, 492-498.

van Belkum, M. J., KoK, J., Venema, G., Holo, H., Nes, I. F., Konings, W. N. \& ABEE, T. (1991b). The bacteriocin lactococcin A specifically increases the permeability of lactococcal cytoplasmic membranes in a voltage-independent, protein mediated manner. Journal of Bacteriology 173, 7934-7941.

Bhunia, A. K., Johnson, M. C. \& Ray, B. (1988). Purification, characterization and antimicrobial spectrum of a bacteriocin produced by Pediococcus acidilactici. Journal of Applied Bacteriology 65, 261-268.

Buchman, G. W., Banerjee, S. \& Hansen, J. N. (1988). Structure, expression, and evolution of a gene encoding the precursor of nisin, a small protein antibiotic. Journal of Biological Chemistry 263, 16260 16266.

Cornwell, G. G., Sletten, K., Johansson, B. \& Westemark, P. (1988). Evidence that the amyloid fibril protein in senile systemic amyloidosis is derived from normal prealbumin. Biochemical and Biophysical Research Communications 154, 648-653.

DAESCHEL, M. A. \& KLAENHAMmer, T. R. (1985). Association of a 13.6megadalton plasmid in Pediococcus pentosaceus with bacteriocin activity. Applied and Environmental Microbiology 50, 1538-1541.

DoDd, H. M., HoRN, N. \& Gasson, M. J. (1990). Analysis of the genetic determinant for production of the peptide antibiotic nisin. Journal of General Microbiology 136, 555-566.

Fyxse, E.-M., Sletten, K., Husby, G. \& CoRnwell, G. G. (1988). The primary structure of the variable region of an immunoglobulin IV light-chain amyloid-fibril protein (AL GIL). Biochemical Journal 256, 973-980.

Geis, A., JasJit, J. \& Teuber, M. (1983). Potential of lactic streptococci to produce bacteriocin. Applied and Environmental Microbiology 45 , 205-211. 
GonZalez, C. F. \& KunKa, B. (1987). Plasmid-associated bacteriocin production and sucrose fermentation in Pediococcus acidilactici. Applied and Environmental Microbiology 53, 2534-2538.

Gross, E. \& Morell, J. (1971). The structure of nisin. Journal of the American Chemical Society 93, 4634-4635.

Hastings, J. W., Sailer, M., Johnson, K., Roy, K. L., Vederas, J. C. \& STILES, M. (1991). Characterization of leucocin A-UAL 187 and cloning of the bacteriocin gene from Leuconostoc gelidum. Journal of Bacteriology 173, 7491-7500.

Henderson, J. T., Chopko, A. L. \& van Wassenaar, P. D. (1992). Purification and primary structure of pediocin PA-1 produced by Pediococcus acidilactici PAC-1.0. Archives of Biochemistry and Biophysics 295 (in the Press).

Holo, H., Nilssen, Ø. \& Nes, I. F. (1991). Lactococcin A, a new bacteriocin from Lactococcus lactis subsp. cremoris: isolation and characterization of the protein and its gene. Journal of Bacteriology 173, 3879-3887.

Hurst, A. (1981). Nisin. Advances in Applied Microbiology 27, 85-123. Joerger, M. C. \& KLAenhammer, T. R. (1990). Cloning, expression, and nucleotide sequence of the Lactobacillus helveticus 481 gene encoding the bacteriocin helveticin J. Journal of Bacteriology 172, 6339-6347.

KaletTA, C. \& Entian, K. D. (1989). Nisin, a peptide antibiotic: cloning and sequencing of the nis $A$ gene and posttranslational processing of its peptide product. Journal of Bacteriology 171, 15971601 .
Klaenhammer, T. R. (1988). Bacteriocins of lactic acid bacteria. Biochimie 70, 337-349.

Mørtyedt, C. I., Nissen-Meyer, J. \& Nes, I. F. (1991). Purification and amino acid sequence of lactocin $\mathrm{S}$, a bacteriocin produced by Lactobacillus sake L45. Applied and Environmental Microbiology 57, 1829-1834.

Muriana, P. M. \& K LAenhammer, T. R. (1991 a). Cloning, phenotypic expression, and DNA sequence of the gene for lactacin $F$, an antimicrobial peptide produced by Lactobacillus spp. Journal of Bacteriology 173, 1779-1788.

Muriana, P. M. \& Klaenhammer, T. R. (1991 b). Purification and partial characterization of lactacin $F$, a bacteriocin produced by Lactobacillus acidophilus 11088. Applied and Environmental Microbiology 57, 114-121.

SAHL, H.-G., KoRDEL, M. \& BENZ, R. (1987). Voltage-dependent depolarization of bacterial membranes and artificial lipid bilayers by the peptide antibiotic nisin. Archives of Microbiology 149, 120-124.

SLETTEN, K. \& HuSBY, G. (1974). The complete amino acid sequence of non-immunoglobulin amyloid protein AS in rheumatoid arthritis. European Journal of Biochemistry 41, 117-125.

TAGG, J. R., Dajani, A. S. \& Wannamaker, L. W. (1976). Bacteriocins of gram-positive bacteria. Bacteriological Reviews 40, 722-756.

TichaczeK, P. S., Nissen-Meyer, J., Nes, I. F., Vogel, R. F. \& HAMMES, W. P. (1992). Characterization of the bacteriocins curvacin A and sakacin P produced by Lactobacillus curvatus LTH1174 and $L$. sake LTH673. Systematic and Applied Microbiology 15 (in the Press). 